Review Paper:

\title{
A Review Study on Self-compassion and Its Place in Psychological Health
}

\author{
Atieh Hosseini Barzanji ${ }^{1}$, Bahman Kurd ${ }^{1 *} \mathrm{C}$
}

1. Department of Psychology, Mahabad Branch, Islamic Azad University, Mahabad, Iran.

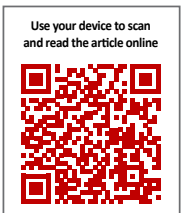

Cftation Kurd B, Hosseini Barzanji A. A Review Study on Self-compassion and Its Place in Psychological Health. Avicenna J of Neuropsychophysiology. 2019; 6(2):57-66. http://dx.doi.org/10.32598/ajnpp.4.3.400

http://dx.doi.org/10.32598/ajnpp.4.3.400

\section{$\omega \theta$}

Article info:

Received: 13 Sep 2018

Accepted: 15 Feb 2019

Available Online: 01 May 2019

Keywords:

Self-compassion, Psychological health, Review study

\section{A B STRACT}

Background: Self-compassion is a construct of mental health that facilitates acceptance and understanding without judgment of difficult mental conditions. It is also effective in creating positive emotions and improving mental well-being.

Objectives: The aim of this study is to review the concept of self-compassion in psychological health.

Materials and Methods: In this review study, the international and Persian databases, such as MEDLINE, PsycINFO, Google Scholar, Cochrane Library, SID, PubMed, and ProQuest were searched by "title search method". Articles were surveyed without a time limit, using the keywords of "selfcompassion" and "psychological health". The articles containing inclusion criteria were separately selected, reviewed, and analyzed. To extract the data, the final articles included in the process of the study were extracted based on a premade checklist.

Results: Out of 54 articles, 48 were excluded because of ignoring the relationship between the "selfcompassion" and "psychological health", as well as lacking a tool for controlling the psychological health and repetitiveness. Finally, 6 articles with the mentioned features were included in the study. Most review studies have shown that self-compassion increases psychological health and promotes well-being.

Conclusion: As a positive construct, self-compassion includes self-kindness, social relationships, and mindfulness, and it is effective in promoting psychological health.

\section{Introduction}

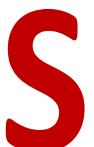

elf-compassion is a positive psychological trait aimed at improving conditions and accepting the abilities and psychological well-being of people, who usually use positive emotions and more adaptive strategies in dealing with stressful life situations. Self-compassion is essentially a kind of mindfulness that allows one to understand and accept the most painful excitement of life without being

* Corresponding Author:

Bahman Kurd, PhD.

Address: Department of Psychology, Mahabad Branch, Islamic Azad University, Mahabad, Iran.

Tel: +98 (914) 3800915

E-mail: b.kurd@iau-mahabad.ac.ir 
disillusioned [1]. Neff showed that people, who have a high degree of self-compassion, usually have a balanced view and insight along with positive thinking and selfcare because they do not persist in the inevitable pain and feelings of defeats that they experience through intense and self-verbal reproaches, isolation, loneliness, and magnifications $[2,3]$.

Self-compassion consists of 3 bipolar components; self-kindness versus self-judgment, sense of common humanity versus isolation, and mindfulness versus over-identification. These components are mutually interacting and require a kind of moving from the tough psychological conditions to the improvement. This structure requires a sense of acceptance and kindness toward oneself (loving-kindness toward oneself) and it cannot be blocked by harsh judgments and prejudices, but individuals equipped with this positive psychological empowerment in difficult psychosocial conditions, with an emphasis on human affinity, emphasize social affinities and implies the perception that all human beings are mistaken, and their activities are always may be resulted in mistaken and even fail, it is not necessarily complete [4].

Undoubtedly, every human being may have failures, mistakes, or ineffective behaviors in life. The person places his personal conflicts and pitfalls at the center of his attention so that he will indirectly have extreme reactions. As he/she considers pain, suffering and defeat are not a logical process of thinking, but a kind of tunnel thinking and vision, in which the real image is lost. Instead, the main focus is solely on themselves as weak and inefficient people. These inadequate responses and conceptualizations of themselves may result in the isolation and separation of the individual from the rest of the community. It results in the formation of something like the personal fable, which is usually seen among adolescents since teens are in conflict with their own problems and believe that their personal experience is unique and they are highly self-centered [5].

On the other hand, a person, who is self-compassioned, has a wider perspective; he/she considers the challenges of life and personal failures as a part of human life and has common sense. The sense of common humanity can correct the concept of personality and self-centeredness and, when a person is under stress, it helps to connect more socially to the people around before he/she is separated from them. Before they see themselves isolated, self-compassioned people see themselves as members of their circles, such as family or community members [6-8]. Therefore, the nature of the sense of common humanity in a harsh psychological condition not only makes it difficult to feel isolated but also emphasizes maintaining more social cohesion. Another factor affecting the formation of self-compassion is mindfulness. The adoption of mindfulness involves "openness to experience" for the reality of the present moment so that any thought and excitement without judgment, avoidance, and repression will be experienced in the direction of consciousness [9].

Mindfulness has defined consciousness in a specific and targeted way at a given time without judgment or prejudgment [10]. Cardaciotto introduces mindfulnessawareness as a cognitive state that is deliberately and consciously focused and can increase the capacity and ability of the information processing system [11]. It increases awareness, transparency, and acceptance of reality at present. Mindfulness restricts the tendency toward painful excitement and oppression. It allows the person to see and experience the unpleasant feeling he/she encounters. In other words, in the mindfulness, what is happening at the moment will be understood without drowning in negative thoughts, feelings, and magnification [12-13]. Enlarging thoughts and negative feelings limit concentration and thinking and, consequently, exaggeration occurs [14]. Usually, such judgments are made: "not only am I failed but I am a loser", "I cannot", and "my life is destroyed". In magnification, he sees himself as a helpless and miserable individua and exaggerates in expressing and illustrating reality, while mindfulness allows us to have a more objective and conscious view of ourselves and life and helps us avoid magnification.

Mindfulness increases self-awareness emotion and can affect emotional regulation. Therefore, self-compassion has been effective in increasing positive emotions and decreasing negative ones and it is effective in regulating emotions [15]. Thus, mindfulness is a balanced mental framework that avoids magnification of situations and provides an opportunity for an individual to escape from unpleasant emotional states and the emergence of instability in excitement. Instead of exacerbating various stresses, the field of psychological growth provides welfare. In the same vein, Hollis-Walker and Colosimo [16] stated that regarding the role of mindfulness in psychological well-being, having mindfulness with increasing psychological well-being and psychological functions reduces the symptoms of pain and stress among the injured people.

Most studies on self-decomposition have been conducted, using a self-compassion scale, which evaluates 
its own degree of cognition. It is also used in Iran on the same scale that Kord and Sharifi [17] and Momeni et al. [18] have standardized. This scale is used for expressing the thoughts, feelings, and behaviors associated with self-compassion components. These components examine how people react to unreliable or painful feelings. Exploratory factor analysis is used to investigate the structural validity of this scale. In factor analysis, using the method of analysis, 6 main component factors (self-control versus self-criticism, the sense of humanity versus isolation, and mindfulness versus more replication or magnification), which, in total, explains $75.12 \%$ of the total scale variance, have been recognized.

Studies show that individuals, who have higher grades on their own scale, have achieved higher levels of happiness, optimism, life satisfaction, body satisfaction, competencies, and suitable physiological reactions against stress [19-22]. Similarly, researchers increasingly use other methods to examine the relationship between selfefficacy and mental health, including outcomes of the mood [23], behavioral observations [24], and short-term and long-term interventions [25]. Also, self-compassion was related to the lower levels of depression, anxiety, stress, body dissatisfaction, and fear of failure [26-28].

Studies show that self-compassion has an inverse relationship with psychological damage. Macbeth and Gumley showed that self-compassion has a negative relationship with negative emotions in 20 studies. The extraordinary size of the great effect and self-examination is an important predictor of anxiety and depression [29]. Therefore, self-compassion is still a negative predictor of anxiety and depression, especially when it is controlled by self-criticism and negative emotions. Selfcompassion is also accompanied by a reduction in intellectual rumination and perfectionism; moreover, selfcompassion facilitates encountering and responding to negative events [30]. An experimental study by Leary et al. showed that those, who are at higher levels in their own traits, are rarely inferior to severe reactions, negative excitements, and negative thoughts. They easily recognize the responsibility for their behaviors toward those, who have lower self-compassion [31].

It is worth noting that self-compassion does not completely eliminate or conceal the negative emotions, but reduces negative thoughts and negative emotional responses. Neff et al. simulated a job interview for their participants, who were asked to "state their biggest weakness". The results showed that those, who had more self-compassion, used a special style in their language when they wrote about their weaknesses, which showed social affinity. For example, they used less "the first-person pronoun", using the word "I"; in contrast, they used more the collective pronouns like "we" and pointed to social resources such as friends, families, and other social resources [32]. These findings show that self-compassion reduces the inconsistency of emotional responses because their weaknesses do not lead to isolation and separation from the community because of the experience of the sense of human involvement.

Self-compassion has also a significant relationship with emotional intelligence, personal initiative, curiosity, intellectual flexibility, and community-related emotions. These are important components of a meaningful life. Additionally, self-compassion is consistent with the feelings of autonomy, competence, dependency, and self-evaluation [33], suggesting that self-adaptation is related to the basic psychological needs raised by Ryan and Deci. Self-decomposition is an important tool for success in dealing with a variety of problems. Individuals with more self-compassion have more emotional balance, work better in their everyday life, and feel less pain in chronic diseases [34-35]. It can also be an important protective agent for post-traumatic stress disorder (PTSD) [36]. Hiraoka et al. showed that disabled soldiers, who returned from the Iraq and Afghanistan war, were less likely to experience PTSD symptoms at their optimal level [37].

As self-compassion is based on positive emotions, it leads to healthier psychological performance. People who are not self-compassioned are more likely are those who have had criticizing mothers in their childhood and have experienced inefficient families and patterns of unpleasant and difficult attachment [38-39]. Inappropriate emotional behaviors in childhood are associated with lower self-compassion, and those with low self-compassion are more anxious and more likely to have alcohol abuse, substance abuse, or seriously committing suicide [40-41].

Therefore, the findings show that self-mediating is the role of mediation related to the relationships between childhood abuse and emotional maladaptation. In this sense, those, who have been abused and have higher levels of self-sufficiency, can cope with inconvenient incidents better compared to fewer people [41] and this suggests that self-compassion is considered a major contributor to the damaged behavior of children.

Self-compassionate is a key mechanism in the effectiveness of mind-awareness therapy interventions, including Mindfulness-based Cognitive Therapy (MBCT) 
[42]. Kuyken et al. showed increased awareness and self-compassion after having participated in a cognitivebased therapy program, which reduced the symptoms of depression in a 15-month period and reduced the depression relapse [43]. These findings suggest that selfcompassion is viewed as an important key to changing thinking patterns permanently and inefficient schemas to prevent depression and depression relapse. Mindfulness-based stress reduction Kabat-Zinn [43] and MBCT such as relaxation, sitting exercises, strolling, and some Yoga exercises [44-45]. The awareness of consciousness, which is a part of its own structure, is improving academic performance and reducing mental retardation and negative emotions [46-47].

In the same vein, a factor between mindfulness and compassion, which plays an important role in explaining well-being mentality and increasing mindfulness by reducing mood and stress in them [48]. Therefore, according to the mentioned cases and emphasizing that a review article on self-compassion and psychological well-being has not been conducted in Iran, the aim of this study was to systematically review previous studies in the field of self-compassion and its relationship with psychological well-being. Accordingly, the researchers have already considered, according to several studies, the researchers intended to prepare a proper review article in this regard.

\section{Materials and Methods}

This research is a narrative review study that focuses on the concept of self-compassion and psychological health without a time limit in seeking and collecting articles (Figure 1). The scientific databases, such as PubMed, Cochrane Library, ProQuest, SID, Google Scholar, PsycINFO, and Medline were searched.

Firstly, the quality of the extracted articles was examined by the reviewers. Then, the review, descriptive, and experimental articles containing criteria such as proper measuring instruments for self-assessment and psychological health, as well as the relationship between selfassessment and psychological health (written in English or Persian languages) were reviewed and analyzed.

All papers collected by researchers were evaluated in terms of quality (the type of study, environments and sample size, and measurement tools). To extract the data, all final papers were processed based on a premade checklist. The checklist contains the name of the author and the year of the study, the study purpose, the

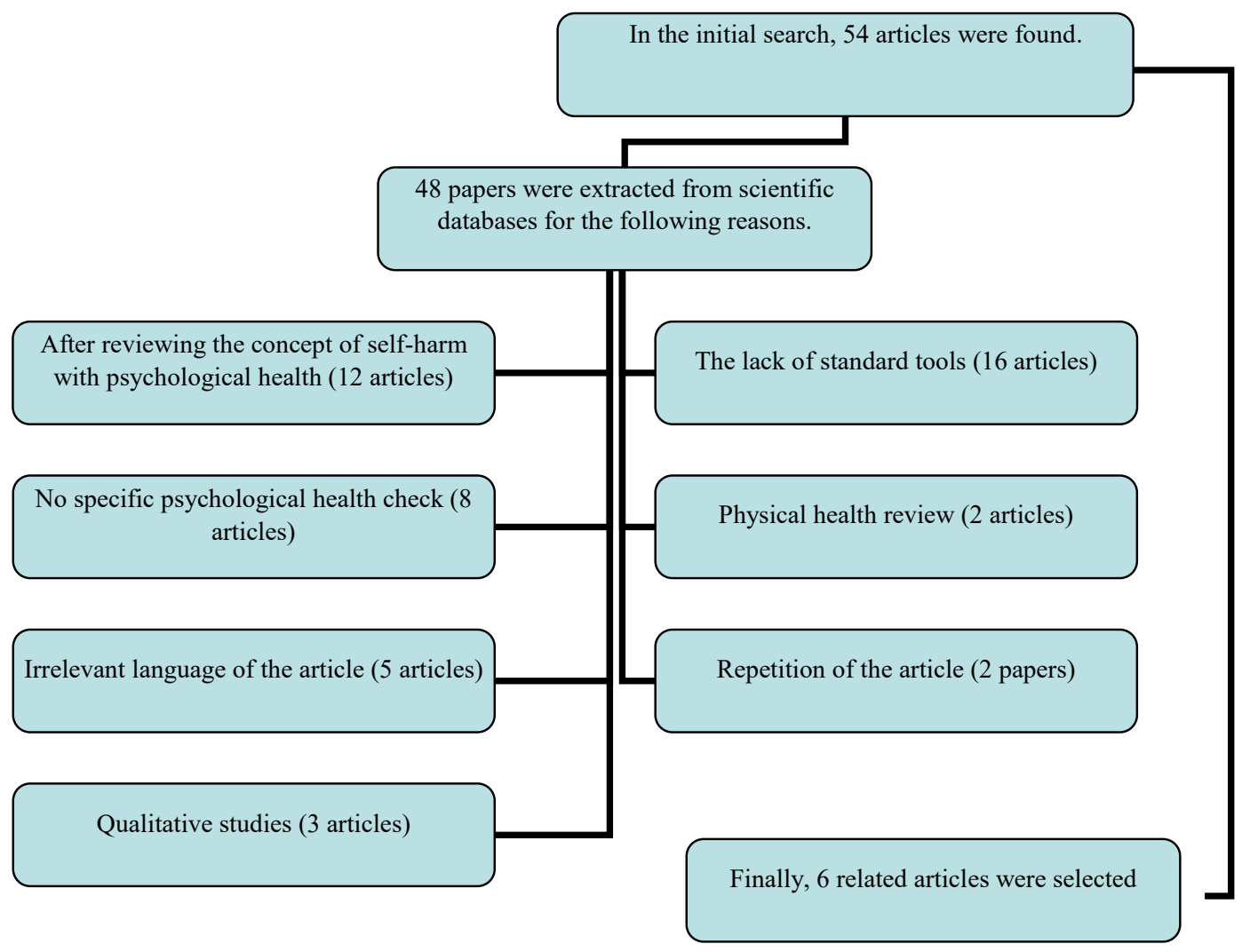

Figure 1. Flowchart of selection of the articles 
sample size and the environment, tools for measuring variables, method, and data collection.

\section{Results}

In the present study, after searching for the necessary studies from 54 initial articles, 48 articles were eliminated because of the lack of correlation between self-compassion and psychological health, the lack of psychological health tools, the lack of standard tools, psychological health inappropriateness, irrelevant language to the topic, and the repetitiveness of the articles. Finally, 6 articles that examined the relationship between self-compassion and psychological health were studied (Table 1).

\section{Discussion}

The aim of this study is locating self-compassion in psychological health. Self-compassion and its components affect psychological health and in as much as the enjoyment of self-compassion increases, the level of psychological well-being will be directly improved [1-4]. It definitely has a reverse relationship with psychological traumas, such as anxiety and depression, and reduces negative and incompatible emotional responses [30-31].

Giving the positive psychological capacities, such as self-kindness, social competency, and mindfulness, people with the self-compassion characteristics rarely show severe reactions and negative automatic thoughts because self-compassion is associated with basic psychological needs [33]. Individuals with more self-compassion are more emotionally balanced and an important protective factor for PTSD [36] because self-compassion is a powerful source of coping with stressful situations and it has a direct relationship with basic psychological needs [24].

The reality of its own structure is the focus on the sentimental feelings, the perception and acceptance of itself, and the recognition of the common sense of the human being, who is under the strict psychological conditions, instead of severe criticisms, and cares about himself with self-discipline and adaptive behavior. From this point of view, one has achieved mental health. He will have an understanding and acceptance of his activities and will take care of himself. Therefore, this positive attitude leads to self-care, by which one cannot blame himself in the face of defeats, loss, and debris. In contrast, he consciously and constantly focuses on understanding the basic processes of the world of his mind. It allows him to experience first-hand experiences with full vigilance and care about himself in his own mind.
One of the cognitive-behavioral therapies that have a great impact on reducing mental stress is mindfulness. It is a kind of ability to live better that prevents exaggeration and excessive magnification [42]. Mindfulness is a concept of consciousness relevant to "here" and "now" and instead of exacerbating pressures, it provides the field of growing, which results in increasing positive emotions and excitements. Hence, mindfulness can improve the quality of life and evaluate life-threatening situations with less stress and more adaptive to stressful situations. Additionally, studies have also shown that mindfulness-based therapeutic interventions, including $\mathrm{MBCT}$, reduced the symptoms of depression and other negative emotions, as well as depression relapse [43].

It usually allows the development of systems to relieve and provide balancing emotional systems because CFTbased interventions focus on developing internalized capabilities and creating the experience of positive emotions. Self-compassion reduces hostility and develops one's ability to create self-confidence and self-esteem. Through their high self-care capacity, self-compassioned people are trying to replace suffering pain with the endeavor, which is the consequence of increasing social cohesion and social interaction with others; all are social interactions and represent psychological health. Therefore, self-compassion concept and its structure is a positive psychological construct with a positive impact on psychosocial health.

Today, the study of self-compassion in various fields of psychology is growing rapidly, but there are still issues of self-compassion that are unclear and are necessary to be investigated in future studies. For example, are there any hidden objections to training and practicing self-compassion? Is there any fundamental difference between self-compassion in age groups, genders, cultures, and social classes? Undoubtedly, answering such questions involves numerous studies that may have not been reviewed so far or just there are limited ones. The right way to check whether self-compassion results in increasing psychological well-being is by conducting research by researchers on themselves. Nowadays, researchers are increasingly using the scientist-practitioner model [51]. As the researcher considers himself a participant, he examines his own "experience of his own life" about self-compassion with all the dimensions, features, and processes, and directly explores its processes. Therefore, it is recommended that researchers in the psychological contexts, in a phenomenological way, provide a thorough understanding of their explanation and analysis in order to provide genuine knowledge of this subject. Also, the majority of research on 
Table 1. Studies on self-compassion in psychological health

\begin{tabular}{|c|c|c|c|c|c|}
\hline $\begin{array}{l}\text { Author (S) } \\
\text { and Year }\end{array}$ & Purpose of the Study & $\begin{array}{l}\text { Population and } \\
\text { Sample Size }\end{array}$ & $\begin{array}{l}\text { Measuring Instrumen- } \\
\text { tation }\end{array}$ & $\begin{array}{l}\text { Method and Data } \\
\text { Collection }\end{array}$ & Key Results \\
\hline 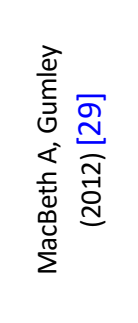 & $\begin{array}{l}\text { A systematic search } \\
\text { of the literature on } \\
\text { compassion and } \\
\text { mental health }\end{array}$ & $\begin{array}{l}\text { The initial search } \\
\text { strategy gener- } \\
\text { ated } 728 \text { articles. } \\
\text { After a review of } \\
\text { abstracts, } 32 \text { po- } \\
\text { tentially fulfilled } \\
\text { the eligibility } \\
\text { criteria. }\end{array}$ & $\begin{array}{l}\text { All studies used SCS } \\
\text { (Neff, 2003a) [5]. }\end{array}$ & $\begin{array}{l}\text { A primary meta-anal- } \\
\text { ysis was conducted } \\
\text { on all identified } \\
\text { studies. Analyses } \\
\text { were calculated, } \\
\text { using Comprehen- } \\
\text { sive Meta-Analysis } \\
\text { version } 2.2 .046 \text { and } \\
\text { IBM SPSS v. } 20 \text { (SPSS, } \\
\text { Chicago, Illinois). }\end{array}$ & $\begin{array}{c}\text { Compassion is an impor- } \\
\text { tant explanatory variable } \\
\text { in understanding mental } \\
\text { health. }\end{array}$ \\
\hline 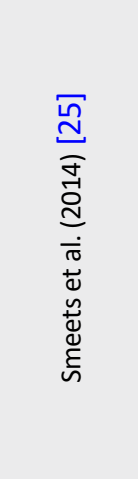 & $\begin{array}{l}\text { The effectiveness of } \\
\text { a newly developed } \\
\text { 3-week self-compas- } \\
\text { sion group interven- } \\
\text { tion for enhancing } \\
\text { resilience and well- } \\
\text { being }\end{array}$ & $\begin{array}{l}\text { Fifty-two female } \\
\text { college students } \\
\text { were randomly } \\
\text { assigned to } \\
\text { either an inter- } \\
\text { vention group } \\
\text { (designed to } \\
\text { teach skills of } \\
\text { self-compassion; } \\
n=27 \text { ) or an ac- } \\
\text { tive control group } \\
\text { (in which general } \\
\text { time manage- } \\
\text { ment skills were } \\
\text { taught; } n=25 \text { ). }\end{array}$ & $\begin{array}{l}\text { To measure resil- } \\
\text { ience and well-being, } \\
\text { participants filled out } \\
\text { a number of question- } \\
\text { naires before and after } \\
\text { the intervention. }\end{array}$ & $\begin{array}{l}\text { Both interventions } \\
\text { comprised } 3 \text { group } \\
\text { meetings held over } 3 \\
\text { weeks. }\end{array}$ & $\begin{array}{l}\text { The self-compassion } \\
\text { intervention led to } \\
\text { significantly greater } \\
\text { increases in mindful- } \\
\text { ness, optimism, and } \\
\text { self-efficacy, as well as } \\
\text { significantly greater } \\
\text { decreases in rumination } \\
\text { in comparison to the } \\
\text { active control interven- } \\
\text { tion. Both interventions } \\
\text { increased life satisfaction } \\
\text { and connectedness. }\end{array}$ \\
\hline 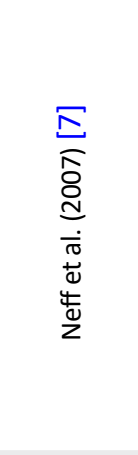 & $\begin{array}{l}\text { The relationship } \\
\text { between self-compas- } \\
\text { sion and psychologi- } \\
\text { cal health. }\end{array}$ & $\begin{array}{l}\text { Participants } \\
\text { included } 91 \\
\text { undergraduates } \\
(22 \text { men and } 69 \\
\text { women with the } \\
\text { Mean } \pm S D \text { age of } \\
20.9 \pm 1.5 \text { years) } \\
\text { from an educa- } \\
\text { tional-psychology } \\
\text { subject pool at a } \\
\text { large southwest- } \\
\text { ern university. }\end{array}$ & $\begin{array}{l}\text { Participants were } \\
\text { given the 26-item SCS } \\
\text { (Neff, 2003) [3]. }\end{array}$ & $\begin{array}{l}\text { The study was } \\
\text { carried out in a } \\
\text { campus computer } \\
\text { lab with groups of } \\
\text { approximately 10-20 } \\
\text { students each. Stu- } \\
\text { dents first filled out } \\
\text { a series of self-report } \\
\text { measures, which } \\
\text { assessed demo- } \\
\text { graphic information, } \\
\text { self-compassion, } \\
\text { self-esteem, negative } \\
\text { affects, and anxiety. }\end{array}$ & $\begin{array}{l}\text { This study found that } \\
\text { self-compassion (unlike } \\
\text { self-esteem) helps buVer } \\
\text { against anxiety when } \\
\text { faced with an ego-threat } \\
\text { in a laboratory setting. } \\
\text { Self-compassion was } \\
\text { also linked to connect } \\
\text { versus separate language } \\
\text { use when writing about } \\
\text { weaknesses. }\end{array}$ \\
\hline 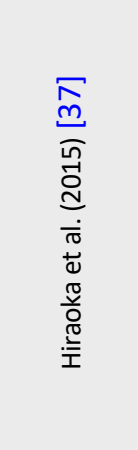 & $\begin{array}{l}\text { Investigating } \\
\text { the relationship } \\
\text { between self-com- } \\
\text { passion and PTSD } \\
\text { symptom severity } \\
\text { after accounting for } \\
\text { the level of combat } \\
\text { exposure and base- } \\
\text { line PTSD severity in } \\
\text { Iraq and Afghanistan } \\
\text { war veterans exposed } \\
\text { to } 1 \text { or more trau- } \\
\text { matic events during } \\
\text { deployment. }\end{array}$ & $\begin{array}{l}\text { The study was } \\
\text { conducted on } \\
115 \text { Iraq and } \\
\text { Afghanistan war } \\
\text { veterans exposed } \\
\text { to } 1 \text { or more } \\
\text { traumatic events } \\
\text { during deploy- } \\
\text { ment. }\end{array}$ & $\begin{array}{l}\text { PTSD symptoms were } \\
\text { assessed, using the } \\
\text { Clinician-Administered } \\
\text { PTSD Scale for DSM-IV } \\
\text { (CAPS-IV). SCS (Neff, } \\
\text { 2003b) is a 26-item } \\
\text { self-report measure. }\end{array}$ & $\begin{array}{l}\text { Correlation matrix } \\
\text { and hierarchical } \\
\text { regression analyses } \\
\text { were used to test } \\
\text { the hypotheses }\end{array}$ & $\begin{array}{c}\text { An increase in self- } \\
\text { compassion is beneficial } \\
\text { for treating chronic PTSD } \\
\text { symptoms among some } \\
\text { Iraq and Afghanistan war } \\
\text { veterans. }\end{array}$ \\
\hline 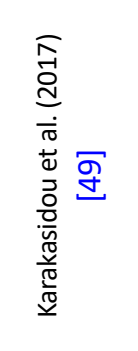 & $\begin{array}{l}\text { This study aimed } \\
\text { at exploring the } \\
\text { effectiveness of a self- } \\
\text { compassion training } \\
\text { program on self- } \\
\text { compassion, positive } \\
\text { and negative effects, } \\
\text { depression, anxiety, } \\
\text { stress, life satisfac- } \\
\text { tion, and subjective } \\
\text { well-being. }\end{array}$ & $\begin{array}{l}\text { The sample } \\
\text { population } \\
\text { comprised } 74 \\
\text { students of } \\
\text { social sciences at } \\
\text { Panteion Univer- } \\
\text { sity of Greece, } \\
\text { of whom } 5 \text { were } \\
\text { males and } 69 \\
\text { were females. }\end{array}$ & $\begin{array}{l}\text { Participants were } \\
\text { given the Greek ver- } \\
\text { sion of the 26-item } \\
\text { SCS (Neff, 2003), which } \\
\text { was translated by } \\
\text { Mantzios, Wilson \& } \\
\text { Giannou (2015). }\end{array}$ & $\begin{array}{l}\text { All participants were } \\
\text { randomly assigned } \\
\text { to the self-compas- } \\
\text { sion intervention } \\
\text { group }(n=33) \text { and the } \\
\text { control group }(n=41) .\end{array}$ & $\begin{array}{l}\text { The intervention group } \\
\text { experienced increases in } \\
\text { self-compassion, positive } \\
\text { affect, life satisfaction, as } \\
\text { well as subjective well- } \\
\text { being and decreases in } \\
\text { negative affect, depres- } \\
\text { sion, anxiety, and stress } \\
\text { scores. }\end{array}$ \\
\hline
\end{tabular}




\begin{tabular}{|c|c|c|c|c|c|}
\hline $\begin{array}{l}\text { Author (S) } \\
\text { and Year }\end{array}$ & Purpose of the Study & $\begin{array}{l}\text { Population and } \\
\text { Sample Size }\end{array}$ & $\begin{array}{l}\text { Measuring Instrumen- } \\
\text { tation }\end{array}$ & $\begin{array}{l}\text { Method and Data } \\
\text { Collection }\end{array}$ & Key Results \\
\hline $\begin{array}{c}\text { Kyeong } \\
\text { (2013) [50] }\end{array}$ & $\begin{array}{l}\text { The moderating effect } \\
\text { of self-compassion } \\
\text { was examined in the } \\
\text { relationship between } \\
\text { the academic burden } \\
\text { and psychological } \\
\text { health. }\end{array}$ & $\begin{array}{l}\text { The participants } \\
\text { were } 350 \text { uni- } \\
\text { versity students, } \\
\text { who were taking } \\
\text { one of several } \\
\text { undergraduate } \\
\text { courses in coun- } \\
\text { seling psychol- } \\
\text { ogy ( } 80 \text { men and } \\
270 \text { women) at } \\
\text { the Seoul Cyber } \\
\text { University during } \\
\text { the } 2011 \text { fall aca- } \\
\text { demic semester. }\end{array}$ & $\begin{array}{l}\text { SCS (Neff, 2003a) is a } \\
\text { 26-item questionnaire } \\
\text { designed to mea- } \\
\text { sure } 3 \text { components } \\
\text { of self-compassion; } \\
\text { self-kindness, common } \\
\text { humanity, and mindful } \\
\text { acceptance. }\end{array}$ & $\begin{array}{l}\text { Data were analyzed, } \\
\text { using multiple re- } \\
\text { gression. All statistics } \\
\text { were tested at an } \\
\text { alpha level of .05. } \\
\text { SPSS/PC V. } 18 \text { was } \\
\text { used for statistical } \\
\text { analysis. }\end{array}$ & $\begin{array}{l}\text { Self-compassion moder- } \\
\text { ated the relationship } \\
\text { between academic } \\
\text { burnout and psycho- } \\
\text { logical well-being. And } \\
\text { self-compassion also } \\
\text { moderated the relation- } \\
\text { ship between academic } \\
\text { burnout and depression. }\end{array}$ \\
\hline
\end{tabular}

AJNPP

PTSD: Post-Traumatic Stress Disorder; DSM-IV: Diagnostic and Statistical Manual of Mental Disorders, Fourth Edition; CAPS-IV: ClinicianAdministered PTSD Scale; SCS: Self-Compassion Scale

self-compassion is the product of solidarity studies that cannot necessarily establish a causal relationship for the confirmation and convergence of the findings. It is necessary to verify self-compassion by using interactive and non-self-reported methods to give more credibility to the data. It turns out that self-compassion is a powerful way to increase psychological well-being.

Considering that studies in this regard in Iran are limited and more psychological health-related areas are not included, it is recommended that planners and policymakers of the psychological health community develop coherent educational programs based on the components of self-governance, the sense of shared humanity, and mindfulness for the promotion of well-being and psychological well-being.

\section{Ethical Considerations}

\section{Compliance with ethical guidelines}

This research does not have the ethics code. However, all ethical principles were considered in this article. The participants were informed about the purpose of the research and its therapeutic stages; they were also assured about the confidentiality of their information. Furthermore, they were allowed to leave the study whenever they wish.

\section{Funding}

This research did not receive any specific grant from funding agencies.

\section{Authors' contributions}

All authors contributed equally in preparing all parts of the research.

\section{Conflict of interest}

The authors declared no conflict of interest.

\section{References}

[1] Neff KD, Germer CK. A pilot study and randomized controlled trial of the mindful self-compassion program.Journal of Clinical Psychology. 2013; 69(1):28-44. [DOI:10.1002/jclp.21923] [PMID]

[2] Neff KD. The development and validation of a scale to measure self-compassion. Self and Identity. 2003; 2(3):223-50. [DOI:10.1080/15298860309027]

[3] Neff KD, Vonk R. Self-compassion versus global self-esteem: Two different ways of relating to oneself. Journal of Personality. 2009; 77(1):23-50. [DOI:10.1111/j.1467-6494.2008.00537.x] [PMID]

[4] Tirch DD. Mindfulness as a context for the cultivation of compassion. International Journal of Cognitive Therapy. 2010; 3(2):113-23. [DOI:10.1521/ijct.2010.3.2.113]

[5] Neff KD, Germer C. Self-compassion and psychological wellbeing. The Oxford Handbook of Compassion Science. Oxford Handbook online; 2017. [DOI:10.1093/oxfordhb/9780190464684.013.27]

[6] Krueger RF, South S, Johnson W, lacono W. The heritability of personality is not always $50 \%$ : Gene-environment interactions and correlations between personality and parenting. Journal of Personality 2008; 76(6):1485-522. [DOI:10.1111/j.1467-6494.2008.00529.x] [PMID] [PMCID]

[7] Kord B, karimi S. [The prediction of emotional regulation based on the students' self-compassion and body image (Persian)]. Journal of Educational Psychology Studies. 2017; 14(28):207-30. [DOI:10.22111/jeps.2017.3601] 
[8] Triandis HC, Suh EM. Cultural influences on personality. Annual Review of Psychology. 2002; 53(1):133-60. [DOI:10.1146/annurev. psych.53.100901.135200] [PMID]

[9] Brown KW, Ryan RM. The benefits of being present: Mindfulness and its role in psychological well-being. Journal of Personality and Social Psychology. 2003; 84(4):822-48. [DOI:10.1037/00223514.84.4.822] [PMID]

[10] Teasdale JD, Segal ZV, Williams JM, Ridgeway VA, Soulsby JM, Lau MA. Prevention of relapserecurrence in major depression by mindfulness-based cognitive therapy. J Consult Clin Psychol. 2000 68:615-23. [DOI:10.1037//0022-006X.68.4.615] [PMID]

[11] Cardaciotto LA. Assessing mindfulness: The develop of a bi-dimensional measure of awareness and acceptance [PhD. dissertation]. Drexel: University of Drexel; 2005.

[12] Holahan CJ, Moos RH. Personal and contextual determinants of coping strategies. Journal of Personality and Social Psychology. 1987; 52(5):946-55. [DOI:10.1037/0022-3514.52.5.946] [PMID]

[13] Kord B, Rahbari P. [The prediction of subjective well-being based on meaning of life and mindfulness among cardiovascular patients (Persian)]. Iranian Journal of Psychiatric Nursing. 2018; 5(6):16-23. [DOI:10.21859/ijpn-05063]

[14] Bishop SR, Lau M, Shapiro S, Carlson L, Anderson ND, Carmody J, et al. Mindfulness: A proposed operational definition. Clinical Psychology: Science and Practice. 2006; 11(3):191-206. [DOI:10.1093/ clipsy.bph077]

[15] Braun TD, Park CL, Gorin A. Selfcompassion, body image, and disordered eating: A review of the literature. Body Image. 2016 17:117-31. [DOI:10.1016/j.bodyim.2016.03.003] [PMID]

[16] Kurd B. [Prediction of Nursing Students' Subjective Well-being based on Mindfulness and Self-compassion (Persian)]. Iranian Journal of Medical Education. 2016; 16:273-82.

[17] Kord B, Pashasharifi H, Mirhashemi M. [Psychometric characteristics self-compassion scale among students (Persian)]. Quarterly Educational Measurement. 2014; 4(16):76-92

[18] Momeni F, Shahidi Sh, Mootabi F. Heydari M. [Psychometric properties of a Farsi version of the Self-Compassion Scale (SCS) (Persian)]. Psychology Contemporary. 2014; 8(2):27-40.

[19] Hollis-Walker L, Colosimo K. Mindfulness, self-compassion, and happiness in nonmeditators: A theoretical and empirical examination. Personality and Individual Differences. 2011; 50(2):222-7. [DOI:10.1016/j.paid.2010.09.033]

[20] Neff KD, Hseih Y, Dejitthirat K. Self-compassion, achievement goals, and coping with academic failure. Self and Identity. 2005 4(3):263-87. [DOI:10.1080/13576500444000317]

[21] Breines JG, Thoma MV, Gianferante D, Hanlin L, Chen X, Rohlede N. Selfcompassionas a predictor of interleukin- 6 response to acute psychosocial stress. Brain, Behavior, and Immunity. 2014; 37:109 14. [DOI:10.1016/j.bbi.2013.11.006] [PMID]

[22] Breines JG, Chen S. Activating the inner caregiver: The role of support-giving schemas in increasing state self-compassion.Journal of Experimental Social Psychology. 2013; 49(1):58-64. [DOI:10.1016/j. jesp.2012.07.015]

[23] Friis AM, Johnson MH, Cutfield RG, Consedine NS. Does kindness matter? Self-compassion buffers the negative impact of diabetes-distress on $\mathrm{HbA}_{1}$. Diabetic Medicine. 2015; 32(12):1634-40. [DOI:10.1111/dme.12774] [PMID]
[24] Sbarra DA, Smith HL, Mehl MR. When leaving your Ex, love yourself: Observational ratings of self-compassion predict the course of emotional recovery following marital separation. Psychological Science. 2012; 23(3):261-9. [DOI:10.1177/0956797611429466] [PMID]

[25] Smeets E, Neff K, Alberts $H$, Peters M. Meeting suffering with kindness: Effects of a brief self-compassion intervention for female college students. Journal of Clinical Psychology. 2014; 70(9):794807. [DOI:10.1002/jclp.22076] [PMID]

[26] Daye CA, Webb JB, Jafari N. Exploring self-compassion as a refuge against recalling the body-related shaming of caregiver eating messages on dimensions of objectified body consciousness in college women. Body Image. 2014; 11(4):547-56. [DOI:10.1016/j.body im.2014.08.001] [PMID]

[27] Finlay-Jones AL, Rees CS, Kane RT. Self-compassion, emotion regulation and stress among australian psychologists: Testing an emotion regulation model of self-compassion using structural equation modeling. PLOS One. 2015; 10(7):e0133481. [DOI:10.1371/journal. pone.0133481] [PMID]

[28] Raes F. Rumination and worry as mediators of the relationship between self-compassionand depression and anxiety. Personality and Individual Differences. 2010; 48:757-61. [DOI:10.1016/j. paid.2010.01.023

[29] MacBeth A, Gumley A. Exploring compassion: A meta-analysis of the association between self-compassion and psychopathology. Clinical Psychology Review. 2012; 32:545-52. [DOI:10.1016/j cpr.2012.06.003] [PMID]

[30] Neff KD. Self-compassion: An alternative conceptualization of a healthy attitude toward oneself. Self and Identity. 2003; 2(2):223 50. [DOI:10.1080/15298860309032]

[31] Leary MR, Tate EB, Adams CE, Allen AB, Hancock J. Self compassion and reactions to unpleasant self-relevant events: The implications of treating oneself kindly. Journal of Personality and Social Psychology. 2007; 92:887-904. [DOI:10.1037/0022-3514.92.5.887] [PMID]

[32] Neff KD, Kirkpatrick K. Rude SS. Self-compassion and its link to adaptive psychological functioning.Journal of Research in Personality. 2007; 41:139-54.[DOI:10.1016/j.jrp.2006.03.004]

[33] Breen WE, Kashdan TB, Lenser, ML, Fincham FD. Gratitude and forgiveness: Convergence and divergence on self-report and informant ratings. Personality and Individual Differences. 2010 49:932-7. [DOI:10.1016/j.paid.2010.07.033] [PMID]

[34] Costa J. Pinto-Gouveia J. Acceptance of pain, self-compassion and psychopathology: Using the chronic pain acceptance questionnaire to identify patients' subgroups. Clinical Psychology \& Psychotherapy. 2011; 18:292-302. [DOI:10.1002/cpp.718] [PMID]

[35] Wren AA, Somers TJ, Wright MA, Goetz MC, Leary MR, Fras AM et al. Self-compassion in patients with persistent musculoskeletal pain: Relationship of self-compassion to adjustment to persistent pain. Journal of Pain and Symptom Management. 2012; 43(4):759 70. [DOI:10.1016/j.jpainsymman.2011.04.014] [PMID]

[36] Thompson BL, Waltz J. Self-compassion and PTSD symptom severity.Journal of Traumatic Stress. 2008; 21(6):556-8. [DOI:10.1002/ jts.20374] [PMID]

[37] Hiraoka R, Meyer EC, Kimbrel NA, DeBeer BB, Gulliver SB, Morissette SB. Self-compassion as a prospective predictor of PTSD symptom severity among trauma-exposed U.S. Iraq and Afghanistan war 
veterans.Journal of Traumatic Stress. 2015; 28:1-7. [DOI:10.1002/ jts.21995] [PMID]

[38] Neff KD, McGeehee P. Self-compassion and psychological resilience among adolescents and young adults. Self and Identity. 2010; 9(3):225-40. [DOI:10.1080/15298860902979307]

[39] Wei M, Liao K, Ku, T, Shaffer P. Attachment, self-compassion, empathy, and subjective well-being among college students and community adults. Journal of Personality. 2011; 79(1):191-221. [DOI:10.1111/j.1467-6494.2010.00677.x] [PMID]

[40] Tanaka M, Wekerle C, Schmuck ML, Paglia-Boak A. The linkages among childhood maltreatment, adolescent mental health, and self-compassion in child welfare adolescents. Child Abuse \& Neglect. 2011; 35(10):887-98. [DOI:10.1016/j.chiabu.2011.07.003] [PMID]

[41] Vettese L, Dyer C, Li W, Wekerle C. Does self-compassion mitigate the association between childhood maltreatment and later regulation difficulties? A preliminary investigation. International Journal of Mental Health and Addiction. 2011; 9:480-91. [DOI:10.1007/ s11469-011-9340-7]

[42] Baer RA. Self-compassion as a mechanism of change in mindfulness and acceptance based treatments. In: Assessing Mindfulness \& Acceptance Processes in Clients, R. A. Baer (ed.) . Oakland: New Harbinger Publications; 2010.

[43] Kuyken W, Watkins E, Holden E, White K., Taylor RS, Byford S, et al. How does mindfulness-based cognitive therapy work? Behaviour Research and Therapy. 2010; 48(11):1105-12. [DOI:10.1016/j. brat.2010.08.003] [PMID]

[44] Kabat-Zinn J. Mindfulness based interventions in context: past, present and future. Clinical Psychology: Science and Practice. 2003; 10(2):144-56. [DOI:10.1093/clipsy/bpg016]

[45] Kabat-Zin J. Full catastrophe living: Using the wisdom of your body and mind to face stress pain and illness. New York: Dell Publishing; 1990.

[46] Samaie Gh, Farahani HA. Self-compassion as a moderator of the relationship between rumination, self-reflection and stress. Social and Behavioral Sciences. 2011; 30:978-82. [DOl:10.1016/j.sbspro.2011.10.190]

[47] Baer RA, Lykins EL, Peters JR. Mindfulness and self-compassion as predictors of psychological wellbeing in long-term meditators and matched nonmeditators. Journal of Positive Psychology. 2012; 7(3):230-8. [DOI:10.1080/17439760.2012.674548]

[48] Kord B, Mehdi pour H. [The relationship between mindfulness and perceived self-efficacy with subjective well-being among cancer patients in Tabriz hospitals (Persian)]. Iranian Journal of Nursing Research. 2018; 13(1):11-7. [DOI:10.21859/ijnr-13012]

[49] Karakasidou E, Stalikas A. The effectiveness of a pilot self-compassion program on well-being components. Psychology. 2017; 8(4):538-49. [DOI:10.4236/psych.2017.84034]

[50] Kyeong LW. Self-compassion as a moderator of the relationship between academic burn-out and psychological health in Korean cyber university students. Personality and Individual Differences

[51] . 2013; 54(8):899-902. [DOI:10.1016/j.paid.2013.01.001]

[52] Lane DA, Corrie S. The modern scientist-practitioner: A guide to practice in psychology. Routledge; 2007. [DOI:10.4324/9780203624616] 
